Ukraine and the decision of the Constitutional Court of Ukraine, introduce "medical reform", which significantly narrows the right to medical care and causes great harm to the population of Ukraine in the exercise of the right to health and life.

Specific proposals are provided to eliminate the negative impact of these rule-making trends and substantiate the thesis of the need to return to social standards in Ukraine to ensure effective and transparent provision of the right to medical care, health and life of citizens of Ukraine.

Current legislation, both at the level of laws and bylaws, contradicts the current Constitution of Ukraine, the decision of the Constitutional Court of Ukraine to ensure the exercise of the right to medical care. Areas of implementation of the so-called "medical reform", which is implemented in Ukrainian society, artificially and significantly restricts the rights of citizens and already has catastrophic consequences for their health and life. Therefore, it is necessary to bring the regulatory framework for medical care in Ukraine in line with constitutional norms, in connection with which to continue research on forms and methods of ensuring the human and citizen's right to medical care.

It can be argued that the legal regulation of the right to medical care and the terrible facts and figures that result from such regulation indicate that the right to medical care in Ukraine is significantly limited, and in some cases completely unattainable for ordinary citizens. What needs to be done to create the conditions for a radical change in this disgraceful state of the healthcare system in Ukraine? If we do not analyze in this study the political, personnel and moral factors of some officials, it is necessary to formulate purely legal advice. Simple implementation of the Constitution of Ukraine, current legislation and decisions of the Constitutional Court of Ukraine solves this issue completely, and does not require revision of doctrinal provisions or radical changes in legislation in this area, only executive discipline and respect for the dignity of Ukrainians.

Keywords: medical care, provision of medical care, medical service, protection of human rights to health and life, legislative provision of protection of human rights, tendencies of legal regulation.

DOI: 10.33766/2524-0323.90.215-227

УДК 342.92: 638.1

А. М. Чвалюк, кандидат юридичних наук, доцент кафедри спеціально-правових дисциплін Донецького державного університету управління (м. Маріуполь, Україна) e-mail: prepod100500@gmail.com iD https://orcid.org/0000-0001-9795-2734

Н. В. Чвалюк, здобувач ступеня вищої освіти «бакалавр» Донецького державного університету управління (м. Маріуполь, Україна) e-mail: nadyashershen@i.ua iDhttps://orcid.org/0000-0003-4348-9208

\title{
СУЧАСНИЙ СТАН ПРАВОВОГО РЕГУЛЮВАННЯ БДЖІЛЬНИЦТВА В УКРАЇНІ
}

Стаття присвячена розгляду сучасного стану правового регулювання бджільництва. Аналіз чинного законодавства, практики діяльності регуляторних органів та наукових до-

(C) Чвалюк А. М.,

Чвалюк Н. В., 2020 
сліджень показав відсутність єдиної спеціалізованої системи державного управління в галузі бджільництва й недостатню ефективність державного контролю. Здійснена спроба привернути увагу до відсутності органів (посадових осіб) уповноважених розглядати справи про адміністративні правопорушення в галузі бджільнищтва; невизначеності підвідомчості справ про адміністративні правопорушення в галузі бджільництва; відсутності правових норм щодо визначення осіб, які мають право складати протоколи про адміністративні правопорушення в галузі бджільництва. Запропоновано включити до положень Державних будівельних норм України наступну вимогу: «На діляниі пасіки вулики мають бути розміщені таким чином: на Відстані не менш ніж 3 м від сусідніх садових (дачних) ділянок льотками, які направлені від них; на відстані не менше ніж 5 м від межі ділянки пасіки з боку вуเuนฺi».

Ключові слова: бджільнищтво, пасіка, мед, управління, контроль, адміністративна відповідальність, Державні будівельні норми України.

Постановка проблеми. Україна - одна з провідних держав світу, яка має розвинуте бджільнищтво, що забезпечує запилення ентомофільних сільськогосподарських рослин, виробництво меду, воску, бджолиного обніжжя, прополісу, бджолиної отрути, бджолиного маточного молочка для потреб населення, харчової, медичної, хімічної та інших галузей. Україну визнають як батьківщину культурного бджільнищтва у світі. Щороку до країн СС експортуються значні обсяги українського меду, що свідчить про значний потенщіал галузі та визначає потребу розвитку бджільнищтва. Через те аналіз проблем та пошук шляхів розвитку зазначеної галузі є актуальним у сучасній аграрній науці.

Аналіз останніх досліджень і публікацій. Вивченням особливостей нормативно-правового забезпечення якості та безпечності меду в Україні і країнах СС на етапах його виробництва та реалізації займалися О. В. Арнаута, В. А. Томчук, О.В.Бернатович (2013) [1]. О. М. Яценко (2009) аналізував механізм державного регулювання якості продукції бджільництва [2]. Група українських учених (В.М.П'ясківський та ін., 2016), проаналізували досвід США та СС у залученні заповідних та охоронних територій для виробництва органічного меду [3]. Серед основних проблем розвитку галузі бджільнищтва в Україні В. Свстаф'єва (2016) визначила зосередженість пасік у приватному секторі, незначні їх розміри, недостатню конщентращію, неконтрольований обмін племінним матеріалом, захворювання бджіл [4]. Г. П. Самчук вважає основними напрямами підвищення конкурентоспроможності галузі таке: підвищення якості продукщіі, створення об'єднань виробників та вихід на ринки СС iз фасованим медом [5]. Білышість із вищезазначених проблем, на нашу думку, можна розв'язати нормативним шляхом, зокрема, гармонізувати національне законодавство з міжнародними нормативними документами, що регулюють виробництво та якість меду й інших продуктів бджільництва.

Формулювання цілей. Метою статі $є$ аналіз сучасного стану правового регулювання бджільництва, виявити деструктивні чинники та сформулювати пропозиції щодо їх усунення на підставі чинного законодавства, практики діяльності регуляторних органів та наукових досліджень.

Виклад основного матеріалу. Законодавча база щодо державного регулювання в галузі бджільництва складається з ряду нормативно-правових актів, основними з яких є: Закони України «Про бджільнищтво» [6], «Про захист рослин» [7], 
«Про ветеринарну медицину» [8]; «Про племінну справу у тваринництві» [9], «Про тваринний світ» [10], «Про рослинний світ» [11], «Про основні принципи та вимоги до безпечності та якості харчових продуктів» [12], Постанова Кабінету Міністрів Украӥни «Питання використання коштів, передбачених у державному бюджеті для фінансової підтримки підприємств агропромислового комплексу» [13]; Накази Міністерства аграрної політики України та Української академії аграрних наук: від 19.06.2015 р. № 234 «Про затвердження Порядку присвоєння відповідного статусу суб'єктам племінної справи у тваринництві та Технологічних вимог до проведення селекційно-племінної роботи в галузі бджільництва» [14], «План породного районування бджіл» [15], «Порядок видачі ветеринарно-санітарного паспорту пасіки» [15], «Порядок реєстрації пасік» [15]; «Правила ввезення в Україну та вивезення за ії межі бджіл і продуктів бджільництва» [15]; Накази Головного державного інспектора ветеринарної медицини України від 27.12.1999 р. № 49 «Про затвердження Порядку пропуску вантажів, підконтрольних службі державної ветеринарної медицини, через державний кордон України» [16], «Інструкція щодо попередження й ліквідації хвороб та отруєнь бджіл» [17] та інші.

Необхідно зауважити, що більшість нормативно-правових актів, які формують законодавство з питань державного регулювання в галузі бджільництва, є частиною адміністративного права, але законодавча база щодо державного регулювання в галузі бджільництва є також частиною аграрного законодавства, якому притаманний комплексний підхід. Це зумовлено тим, що в аграрному секторі економіки функціонує комплекс суспільних відносин, які регулюються нормами різних галузей права: державного, цивільного, фінансового, земельного, адміністративного тощо. При цьому складовими елементами ефективності аграрних законів, у тому числі, що містять адміністративні норми адміністративного характеру, є: державна підтримка сільськогосподарської продукції; конституційність; стабільність закладених у законах правових норм; своєчасність реагування на неефективність законів; відсутність дублювання і прогалин у законі; інформованість громадян про закони; дієвий механізм реалізації закону [18, с. 56-57].

Водночас, цим аграрним законам притаманні й недоліки адміністративноправових норм: наявність окремих правових норм, що мають декларативний характер; закріплення значної частини правових норм не законами, а актами нижчої юридичної сили; нечітка регламентація питання державного регулювання в галузі бджільництва; відсутність реальних заходів адміністративної відповідальності за порушення в галузі бджільництва.

Також вчені звертають увагу на таку проблему в галузі бджільництва, як відсутність єдиного фундаторного акта кодифікованого характеру [19, с. 42]. Лунають пропозищії здійснити систематизацію законодавства в галузі бджільництва шляхом проведення предметної інкорпорації у вигляді збірника нормативних актів «Законодавство України про державне регулювання в галузі бджільництва» [18, с. 65]. На нашу думку, перш ніж починати систематизацію законодавства, його слід оновити у відповідності до вимог часу та інтеграційних прагнень.

Одним із основних законодавчих актів з питань державного регулювання в галузі бджільництва є Закон України «Про бджільництво» (далі - Закон) [6], який регулює відносини щодо розведення, використання та охорони бджіл, виробництва, заготівлі та переробки продуктів бджільництва, ефективного використання бджіл 
для запилення ентомофільних рослин сільськогосподарського призначення, іншших видів запилювальної флори, створення умов для підвищення продуктивності бджіл і сільськогосподарських культур, забезпечення гарантій дотримання прав та захисту інтересів фізичних і юридичних осіб, які займаються бджільництвом.

Згідно зі ст. 7 Закону, державне регулювання в галузі бджільництва здійснюється таким шляхом: визначення загальних засад проведення єдиної науково-технічної політики; встановлення відповідних норм і правил; удосконалення державного управління в галузі бджільництва; організації та забезпечення проведення заходів 3 діагностики, профілактики і боротьби з хворобами та потравами бджіл; розроблення та затвердження технологічних вимог до проведення селекційно-племінної роботи в галузі бджільництва, проведення атестації пасік і видачі племінних свідоцтв (сертифікатів); організації та забезпечення контролю за якістю продуктів бджільнищтва; контролю за експортом та імпортом продуктів бджільнищтва; координації підготовки та перепідготовки спеціалістів із бджільництва; координації селекційно-племінної роботи, сприяння розвитку бджільництва; здійснення контролю за ефективністю запилення ентомофільних рослин сільськогосподарського призначення в порядку, встановленому центральним органом виконавчої влади, що забезпечує формування державної аграрної політики.

Органами державного управління в галузі бджільництва є Кабінет Міністрів України, Міністерство розвитку економіки, торгівлі та сільського господарства, Рада міністрів Автономної Республіки Крим, місцеві державні адміністрації (ст. 6 Закону). Зокрема, згідно з Положенням про Міністерство розвитку економіки, торгівлі та сільського господарства України [20], Міністерство є центральним органом виконавчої влади, діяльність якого спрямовується і координується Кабінетом Міністрів України.

Аналіз структури вищенаведеного міністерства показує, що система спеціалізованих органів державного управління в галузі бджільництва до цих пір не сформована, що підтверджується таким чином: 1) відсутністю спеціалізованих структурних елементів управління на рівні центрального органу виконавчої влади; 2) відсутністю спеціалізованих структурних елементів на місцевому (обласному та районному) рівні; 3) недостатнім державним контролем за дотриманням законодавства в галузі бджільнищтва; 4) відсутністю правових норм, що регулюють найбілыш суттєві питання адміністративної відповідальності за порушення законодавства в галузі бджільнищтва.

Відсутність спеціалізованої системи управління негативно впливає на розвиток галузі, особливо в питаннях проведення селекційно-племінної роботи, дотримання Плану породного районування, організації запилення сільськогосподарських культур, отримання якісної продукції, ветеринарно-санітарного обслуговування, контролю за дотриманням законодавства в галузі бджільництва та в інших питаннях [18, с. 116-117].

Законом передбачено, що право на утримання бджіл і зайняття бджільнищтвом мають громадяни України, іноземці та особи без громадянства, які мають необхідні навички або спеціальну підготовку, а також юридичні особи. Зайняття бджільнищтвом здійснюється без окремого дозволу органу виконавчої влади або органу місцевого самоврядування. Фізична особа, що має намір займатися бджільництвом, 
формує пасіку з бджолиних сімей, яка може мати підсобне приміщення, інвентар та обладнання й розміщується на відповідній земельній ділянщі. 3 метою обліку пасік та здійснення лікувально-профілактичних заходів, на кожну пасіку видається ветеринарно-санітарний паспорт. Пасіка підлягає реєстрації за місцем проживання фізичної особи або за місцем знаходження юридичної особи, яка займається бджільництвом у місцевих державних адміністраціях або сільських, селищних, міських радах у порядку, встановленому центральним органом виконавчої влади з питань аграрної політики. Фізичні та юридичні особи розміщують пасіки на земельних ділянках, які належать їм на правах власності або користування, відповідно до ветеринарно-санітарних правил. Розміщення пасік на земельних ділянках інших власників або користувачів здійснюється за їхньою згодою.

Розміщення й облаштування пасік визначено «Інструкцією щодо попередження та ліквідації хвороб і отруєння бджіл», яка затверджена наказом головного державного інспектора ветеринарної медицини 30.01.2001 p. № 9 та зареестрована в Міністерстві юстиції Украӥни 12.02.2001 р. за №131/5322 [17].

Згідно з Інструкцією, пасіку розміщують на сухих, захищених від вітру місцях, на відстані не ближче 500 м від шосейних доріг і залізнищь, пилорам, високовольтних ліній електропередач, не менше 1 км від тваринницьких і птахівницьких будівель 15 км від воскопереробних заводів, підприємств кондитерської і хімічної промисловості, аеродромів, військових полігонів та інших джерел мікрохвильового випромінювання.

Територію стаціонарної пасіки огороджують, обсаджують плодовими деревами і кущами. Відведення земельних ділянок для розміщення такої пасіки необхідно погоджувати з органами державного управління з питань ветеринарної медицини і місцевими органами влади. При розміщенні пасіки на присадибній ділянщі (подвір'ї) огорожа повинна бути заввишки не менше 2,5 м для підвищення рівня льоту бджіл, але не передбачено, на якій відстані повинні бути розміщені пасіки на присадибних земельних ділянках від суміжних земельних ділянок та житлової забудови та прирівняних до неї об'єктів, тобто на законодавчому рівні не визначений розмір санітарно-захисної зони в метрах [21].

Невизначеність розміру санітарно-захисної зони призводить до того, що між громадянами, які розмістили пасіку на власному подвір'ї та їх сусідами, виникають суперечки. Органи місцевого самоврядування намагаються врегулювати спір, однак пробільність законодавства ускладнює цей процес. Ми пропонуємо заповнити цю пробільність, імплементувавши досвід Республіки Беларусь. Зокрема, пропонується включити до положень Державних будівельних норм Украӥни наступну вимогу: «На ділянці пасіки Вулики мають бути розміщені таким чином: на відстані не менш ніж 3 м Від сусідніх садових (дачних) ділянок льотками, які направлені від них; на Відстані немение ніж 5 м від межі ділянки пасіки з боку вулииіџ. Закріплення зазначених нормативів зменшить кількість конфліктів між населенням та посилить гарантії на безпечне середовище для людей та їхніх домашніх тварин.

Держава гарантує додержання прав і законних інтересів пасічників у галузі бджільництва. Пасічники, здійснюючи господарську діяльність у галузі бджільництва, мають право приймати з власної ініңіативи будь-які рішення, що не суперечать законодавству України. Пасічники мають право на оскарження в суді рішень, дій чи бездіяльності органів державної влади, органів місцевого самоврядування, їх посадових і службових осіб (ст. 10 Закону). 
Відповідно до вимог Закону України «Про бджільнищтво», листа Державної служби України з питань безпечності харчових продуктів та захисту споживачів № 602-113-12/4087 від 14.06.2018 року «Щодо реєстрації пасік», розпорядження Головного державного ветеринарного інспектора України № 67 від 11.06.2018 року, державна реєстрація є обов'язковою для суб'єктів господарювання, які займаються утриманням та розведенням бджіл, виробництвом і первинною переробкою продуктів бджільнищтва в частині дотримання вимог чинного законодавства у сфері бджільництва.

На виконання вимог статті 25 Закону України «Про основні принципи та вимоги до безпечності та якості харчових продуктів» та наказу Міністерства аграрноїполітики та продовольства України «Про затвердження порядку проведення державної реєстрації потужностей, ведення реєстру потужностей операторів ринку та надання інформації 3 нього заінтересованим суб'єктам» від 10.02.2016 р. № 39, необхідно зареєструвати потужності операторів ринку харчових продуктів, які проводять діяльність з обігу харчових продуктів, що не вимагає отримання експлуатащійного дозволу.

Реєстрація потужностей здійснюється на безоплатній основі. Оператору ринку слід лише подати заяву до територіального органу Держпродспоживслужби за місцем розташування потужностей та детальну інформацію про вид діяльності. Власнику пасік необхідно отримати ветеринарно-санітарний паспорт на пасіку, що видається на підставі письмового звернення до управління Держпродспоживслужби в районі або місті з обов' язковим проведенням епізоотичного обстеження. У паспорті мають бути відображені такі дані: характеристика пасіки, ії ветеринарно-санітарний стан, епізоотична обстановка, дані лабораторних досліджень, результати проведених лікувально-профілактичних заходів. Районне (міське) управління Держпродспоживслужби повинне видати в 30-денний термін заявнику ветеринарно-санітарний паспорт пасіки з обов' язковою державною реєстрацією. При зміні назви чи адреси пасіки, іï власник мусить проінформувати про це районне (міське) управління Держпродспоживслужби протягом 10 днів [22]. Власники пасік мають дотримуватися вимог законодавства України з питань бджільництва. Невиконання даних вимог здатне ускладнити чи навіть унеможливити позитивне вирішення спірних питань, які виникають під час ведення господарської діяльності.

Через відсутність єдиної спеціалізованої системи державного управління в галузі бджільництва недостатньо представлений і державний контроль. Згідно із Законом України «Про племінну справу у тваринництві», окремі функції державного контролю в галузі бджільнищтва повинна виконувати Головна племінна інспекція, однак іiї управлінська вертикаль до цього часу ще не сформована. Деякі функції, зокрема: розроблення конщептуальних напрямів розвитку конкурентоспроможного племінного твариннищтва; розроблення пропозицій щодо заходів державного стимулювання племінної справи у твариннищтві, у тому числі щодо збереження генофонду існуючих, локальних та зникаючих вітчизняних порід бджіл, - раніше виконував департамент твариннищтва Міністерства аграрної політики та продовольства України [23]. Проте у зв' язку із реорганізацією міністерств, це коло питань залишилося поза увагою Уряду. 
Окремо слід зазначити, що проведення селекційно-племінної роботи в галузі бджільнищтва, має особливості, які не дозволяють використовувати загальноприйняті в тваринництві методи контролю, зокрема щодо дотримання Плану породного районування бджіл та інших питань [18, с. 130].

Відсутність державного контролю в галузі бджільництва, крім проведення селекщійно-племінної роботи, створює також проблеми щодо контролю дотримання пасічниками технологічних вимог отримання якісної продукції бджільнищтва (у тому числі щодо порушення вимог при профілактиці та лікуванні хвороб бджіл), ефективності запилення ентомофільних сільськогосподарських культур (зокрема щодо оплати за використання бджолиних сімей на запиленні). Це стосується також порушення законодавства в галузі бджільництва, особливо у випадку отруєння бджіл пестицидами [18, с. 131].

Незважаючи на те, що потрава бджіл, за умови заподіяння істотної шкоди (наприклад, потрава великої кількості бджолиних сімей), повністю охоплюються складом злочину, передбаченого статтею 247 Кримінального кодексу України (порушення правил, установлених для боротьби зі шкідниками і хворобами рослин, та інших вимог законодавства про захист рослин, що спричинило тяжкі наслідки), механізм притягнення до відповідальності агровиробників, які порушують норми поводження з ядохімікатами, не працює.

На початку 2019 року було зареєстровано Законопроект № 10052, яким передбачалось доповнити Кримінальний кодекс України статтею 247-1 «Потрава бджіл» [24]. Однак його було відкликано.

Говорячи про проблеми адміністративної відповідальності в галузі бджільництва, необхідно зазначити, що згідно із ст. 38 Закону, відповідальність за порушення законодавства в галузі бджільнищтва тягне за собою дисциплінарну, адміністративну, цивільно-правову або кримінальну відповідальність відповідно до законів України. При чому відповідальність за порушення законодавства в галузі бджільництва несуть особи, винні у такому: неповідомленні (приховуванні) або наданні неправдивої інформації про виникнення загрози бджолам при застосуванні засобів захисту рослин; порушенні технології вирощування рослин сільськогосподарського та іншого призначення, що призвело до погіршення умов в ареалах розселення бджіл; реалізації продуктів бджільництва та їх сумішей, що не пройшли ветеринарно-санітарної експертизи; ухиленні від обов' язкової ветеринарно-санітарної експертизи продуктів бджільництва та їх сумішей; порушенні правил ввезення на територію України та вивезення за їі межі бджіл та продуктів бджільництва; реалізації на території України не зареєстрованих в Україні засобів захисту бджіл.

Шкода, заподіяна внаслідок порушення законодавства про бджільнищтво, відшкодовується в порядку та розмірах, встановлених законодавством України. Спори, що виникають у галузі бджільнищтва, вирішуються судом у встановленому законодавством поряцку.

Однак реалізація адміністративної відповідальності щодо адміністративних правопорушень в галузі бджільництва фактично є неможливою через:

1) відсутність відповідних правових норм щодо адміністративних правопорушень у галузі бджільництва в Кодексі України про адміністративні правопорушення;

2) відсутність органів (посадових осіб) уповноважених розглядати справи про адміністративні правопорушення в галузі бджільнищтва; 
3) невизначеність підвідомчості справ про адміністративні правопорушення в галузі бджільництва;

4) відсутність правових норм щодо визначення осіб, які мають право складати протоколи про адміністративні правопорушення в галузі.

Водночас посилення адміністративної відповідальності в галузі бджільнищтва $\epsilon$ вкрай актуальним. Зокрема, основними адміністративними проступками в галузі бджільнищтва є:

а) недотримання Плану породного районування бджіл;

б) неповідомлення (приховування) або надання неправдивої інформації про виникнення загрози бджолам при застосуванні засобів захисту рослин;

в) недотримання вимог щодо розміщення й облаштування пасік;

г) порушення правил реєстрації та оформлення паспорту пасіки [18, с. 138-140].

Для попередження адміністративних проступків у галузі бджільництва та вирішення проблем адміністративної відповідальності, на думку С. І. Бугери, у галузі необхідно передбачити підрозділ структури державного управління, який би мав відповідні повноваження, а також законодавчо їх закріпити; внести доповнення до Кодексу України про адміністративні правопорушення в питаннях недотримання Плану породного районування бджіл; неповідомлення (приховування) або надання неправдивої інформації про виникнення загрози бджолам при застосуванні засобів захисту рослин; недотримання вимог щодо розміщення й облаштування пасік; порушення правил реєстрації та оформлення паспорту пасіки [18, с. 146]. Ми також приєднуємося до цієї пропозищії.

Висновки. Завершуючи наше дослідження, можна констатувати, що бджільництво - стародавня традищійна галузь сільськогосподарського виробнищтва, основою функціонування якої є розведення, утримання та використання бджіл для запилення ентомофільних рослин сільськогосподарського призначення і підвищення їх урожайності, виробництво харчових продуктів і сировини для господарської діяльності. Однак сучасні соціальні та екологічні вимоги, а також евроінтеграційні прагнення вимагають відійти від традиційної практики бджільництва й почати застосовувати нові підходи до виробництва, управління та контролю і, відповідно, розробити та прийняти нові законодавчі нормативи. На жаль, починаючи з 2013 р., у сфері правового регулювання бджільництва нічого не змінилося. Досі не створено реєстр пасік, а осіб, винних у масовій загибелі бджіл на Сумщині, не можуть притягнути до відповідальності через недосконалість законодавства тощо.

Зміст державного регулювання в галузі бджільництва полягає в регулятивному впливі на об'єкти регулювання з метою досягнення галуззю максимальної ефективності для задоволення попиту населення в продуктах харчування та сировині, однак система органів управління та контролю у сфері бджільництва все ще перебуває на стадії формування.

Система гарантій, особливо прав громадян, які мешкають по сусідству з пасіками, знаходиться у незадовільному стані, тому нами запропоновано включити до положень Державних будівельних норм України наступну вимогу: «На ділянці пасіки вулики мають бути розміщені: на відстані не менш ніж 3 м від сусідніх садових (дачних) ділянок льотками, які направлені від них; на відстані не менше ніж 5 м від межі ділянки пасіки з боку вулиціџ. Ми впевнені, що закріплення зазначених нормативів зменшить 
кількість конфліктів серед населення та посилить гарантії на безпечне середовище для людей та їхніх домашніх тварин.

\section{Використані джерела:}

1. Арнаута О. В. Особливості нормативного забезпечення якості та безпечності бджолиного меду в Україна і СС на етапах його виробнищтва та реалізації. Науковий вісник ЛНАУ. 2013. Вип. 53. С. 5-7.

2. Яценко О. М. Державне регулювання якості продукції бджільнищтва: світовий досвід та вітчизняна практика. Економіка та управління АПК: зб. наук. праць. Біла Церква, 2009. Вип. 1 (66). С. 21-30.

3. П'ясківський В. М., Вербельчук Т. В., Вербельчук С. П., Барановська В. А. Перспективи органічного бджільництва на Поліссі. «Органічне виробництво і продовольча безпека: зб. матер. доп. учасн. IV Міжнар. наук.-практ. конф. Житомир: 2016. С. 170-176.

4. Свстаф'єва В., Назаренко О. Проблеми розвитку бджільництва в Україні. Екологія і природокористування в системі оптимізації відносин природи і суспільства: матер. III Міжн. наук.-практ. конф. 24-25 березня 2016 р. Тернопіль: Крок. 2016. Ч. 2. С. 13-15.

5. Самчук Г. П. Стан та тенденції розвитку вітчизняного та світового ринків меду. Молодий вчений. 2016. № 12.1 (40). С. 658-961.

6. Про бджільнищтво: Закон України від 22 лютого 2000 р. № 1492-ІІІ. Відомості Верховної Ради України. 2000. № 21. Ст. 157.

7. Про захист рослин: Закон України від 14 жовтня 1998 р. Відомості Верховної Ради України. 1998. № 50-51. Ст. 310.

8. Про ветеринарну медицину: Закон України від 25 червня 1992 р. № 2498-XII. Bidoмості Верховної Ради України. 1992. № 36. Ст. 531.

9. Про племінну справу у тваринництві: Закон України від 15 грудня 1993 р. № 3691ХІІ. Відомості Верховної Ради Украӥни. 1994. № 2. Ст. 7.

10. Про тваринний світ: Закон України від 13 грудня 2001 р. № 2894-III. Відомості Верховної Ради України. 2002. № 14. Ст. 97.

11. Про рослинний світ: Закон України від 9 квітня 1999 р. № 591-XIV. Відомості Верховної Ради Украӥни. 1999. № 22-23. Ст. 198.

12. Про основні принципи та вимоги до безпечності та якості харчових продуктів: Закон України від 23 грудня 1997 р. № 771/97-ВР. Відомості Верховної Ради Украӥни. 1998. № 19. Ст. 9.

13. Питання використання коштів, передбачених у державному бюджеті для фінансової підтримки підприємств агропромислового комплексу: Постанова Кабінету Міністрів України від 6 травня 2005 р. № 325. Офіиційний вісник України. 2005. № 19. Ст. 997.

14. Про затвердження Порядку присвоєння відповідного статусу суб'єктам племінної справи у тваринництві та Технологічних вимог до проведення селекційно-племінної роботи в галузі бджільництва: Наказ Міністерства аграрної політики України від 19.06.2015 p. № 234. Офіиційний Вісник України. 2015. № 60. Ст. 1985.

15. Про затвердження нормативно-правових актів з питань розвитку бджільництва: Наказ Міністерства аграрної політики України та Української академії аграрних наук від 20.09.2000 p. № 184/82. Офріційний Вісник Украӥни. 2000. № 43. Ст. 1872.

16. Про затвердження Порядку пропуску вантажів, підконтрольних службі державної ветеринарної медицини, через державний кордон України: Наказ Головного державного інспектора ветеринарної медицини України від 27.12.1999 р. № 49. Офiüiйний вicник Украӥни. 2000. № 2. Ст. 56. 
17. Інструкція щодо попередження та ліквідації хвороб і отруєнь бджіл: Наказ головного державного інспектора ветеринарної медищини від 30 січня 2001 р. № 9. Oфіuіиіний вісник України. 2001. № 7. Ст. 304.

18. Бугера С. І. Організаційно-правові питання розвитку державного регулювання в галузі бджільнищтва України: дис. ... канд. юрид. наук: 12.00.07. Інститут держави і права ім. В. М. Корецького. К., 2007. 219 с.

19. Аграрне право України / за редакцією академіка АПН професора Янчука В. 3. К.: Юрінком, 1996.560 с.

20. Питання Міністерства розвитку економіки, торгівлі та сільського господарства: Постанова Кабінету Міністрів України від 11 вересня 2019 р. № 838. Офіиійний Вісник України. 2019. № 74. Ст. 2588.

21. Про правила утримання бджіл та зайняття бджільництвом. URL: http://radabershad.gov.ua/novunu/pro-pravyla-utrymannya-bdzhil-ta-zaynyattya-bdzhilnyctvom (дата звернення: 15.05.2020).

22. Реєстрація пасік. Сайт головногоуправління Держпродспоживслужбив Херсонській області. URL: https://dpss-ks.gov.ua/novini/reyestraciya-pasik (дата звернення: 15.05.2020).

23. Положення про департамент тваринництва Міністерства аграрної політики та продовольства України. Наказ Міністерства аграрної політики та продовольства України від 21 березня 2016 р. № 96. URL: http:/ / minagro.gov.ua/ uk/ organic_ministry?nid= 2995 (дата звернення: 15.05.2020).

24. Проект Закону про внесення змін до деяких законодавчих актів України щодо захисту бджільництва від 14.02.2019 p. № 10052. URL: http:/ / w1.c1.rada. gov.ua/pls/ zweb2/ webproc4_1?pf3511=65508 (дата звернення: 18.05.2020).

\section{References:}

1. Arnauta, O. V. (2013) Osoblyvosti normatyvnoho zabezpechennia yakosti ta bezpechnosti bdzholynoho medu v Ukraina i YeS na etapakh yoho vyrobnytstva ta realizatsii. Naukoryi visnyk LNAU- Scientific Bulletin of LNAU, 53. [in Ukrainian].

2. Yatsenko, O. M. (2009) Derzhavne rehuliuvannia yakosti produktsii bdzhilnytstva: svitovyi dosvid ta vitchyzniana praktyka. Ekonomika ta upravlinnia APK: zb. nauk. prats. Bila Tserkva - Economics and management of agro-industrial complex: coll. Science, issue 1 (66). [in Ukrainian].

3. P'iaskivskyi, V. M., Verbelchuk, T. V., Verbelchuk, S. P., Baranovska, V. A. (2016) Perspektyvy orhanichnoho bdzhilnytstva na Polissi. «Orhanichne vyrobnytstoo i prodovolcha bezpeka: zb. mater. dop. uchasn. IV Mizhnar. nauk.-prakt. konf. Zhytomyr-"Organicproduction and food security:Coll. mater. ext. participant IV International. scientific-practical conf. Zhytomyr, 170-176. [in Ukrainian].

4. Yevstaf' ieva, V., Nazarenko, O. (2016) Problemy rozvytku bdzhilnytstva v Ukraini. Ekolohiia i pryrodokorystuvannia $v$ systemi optymizatsii vidnosyn pryrody i suspilstoa: mater. III Mizhn. nauk.-prakt. konf. 24-25 bereznia 2016 r.- Ekolohiia i pryrodokorystuvannia v systemi optimizatsii vidnosyn prirody i suspilstva: mater. III Mizhn. scientific-practical conf. March 24-25, 2016. Ternopil: Krok, part. 2, 13-15. [in Ukrainian].

5. Samchuk, H. P. (2016) Stan ta tendentsii rozvytku vitchyznianoho ta svitovoho rynkiv medu. Molodyi vchenyi - A young scientist, 12.1 (40), 658-961. [in Ukrainian].

6. Pro bdzhilnytstvo: Zakon Ukrainy vid 22 liutoho 2000 r. № 1492-III. (2000) Vidomosti Verkhoonoi Rady Ukrainy, 21, art. 157. [in Ukrainian].

7. Pro zakhyst roslyn: Zakon Ukrainy vid 14 zhovtnia 1998 r. (1998) Vidomosti Verkhovnoi Rady Ukrainy, 50-51, art. 310. [in Ukrainian].

8. Pro veterynarnu medytsynu: Zakon Ukrainy vid 25 chervnia 1992 r. № 2498-XII. (1992) Vidomosti Verkhoonoi Rady Ukrainy, 36, art. 531. [in Ukrainian]. 
9. Pro pleminnu spravu u tvarynnytstvi: Zakon Ukrainy vid 15 hrudnia 1993 r. № 3691-XII. (1993) Vidomosti Verkhoonoi Rady Ukrainy, 2, art. 7. [in Ukrainian].

10. Pro tvarynnyi svit: Zakon Ukrainy vid 13 hrudnia 2001 r. 2894-III. (2001) Vidomosti Verkhoonoi Rady Ukrainy, 14, art. 97. [in Ukrainian].

11. Pro roslynnyi svit: Zakon Ukrainy vid 9 kvitnia 1999 r. 591-XIV. (1999) Vidomosti Verkhoonoi Rady Ukrainy, 22-23, art. 198. [in Ukrainian].

12. Pro osnovni pryntsypy ta vymohy do bezpechnosti ta yakosti kharchovykh produktiv: Zakon Ukrainy vid 23 hrudnia 1997 r. 771/97-VR. (1997) Vidomosti Verkhoonoi Rady Ukrainy, 19, art. 9. [in Ukrainian].

13. Pytannia vykorystannia koshtiv, peredbachenykh $\mathrm{u}$ derzhavnomu biudzheti dlia finansovoi pidtrymky pidpryiemstv ahropromyslovoho kompleksu: Postanova Kabinetu Ministriv Ukrainy vid 6 travnia 2005 r. 325. (2005) Ofitsiinyi visnyk Ukrainy, 19, art. 997. [in Ukrainian].

14. Pro zatverdzhennia Poriadku prysvoiennia vidpovidnoho statusu sub'iektam pleminnoi spravy $\mathrm{u}$ tvarynnytstvi ta Tekhnolohichnykh vymoh do provedennia selektsiinopleminnoi roboty $\mathrm{v}$ haluzi bdzhilnytstva: Nakaz Ministerstva ahrarnoi polityky Ukrainy vid 19.06.2015 r. 234. (2015) Ofitsiinyi visnyk Ukrainy, 60, art. 1985. [in Ukrainian].

15. Pro zatverdzhennia normatyvno-pravovykh aktiv z pytan rozvytku bdzhilnytstva: Nakaz Ministerstva ahrarnoi polityky Ukrainy ta Ukrainskoi akademii ahrarnykh nauk vid 20.09.2000 r. 184/82. (2000) Ofitsiinyi visnyk Ukrainy, 43, art. 1872. [in Ukrainian].

16. Pro zatverdzhennia Poriadku propusku vantazhiv, pidkontrolnykh sluzhbi derzhavnoi veterynarnoi medytsyny, cherez derzhavnyi kordon Ukrainy: Nakaz Holovnoho derzhavnoho inspektora veterynarnoi medytsyny Ukrainy vid 27.12.1999. 49. (1999) Ofitsiinyi visnyk Ukrainy, 2, art. 56. [in Ukrainian].

17. Instruktsiia shchodo poperedzhennia ta likvidatsii khvorob i otruien bdzhil: Nakaz holovnoho derzhavnoho inspektora veterynarnoi medytsyny vid 30 sichnia 2001 r. 9. (2001) Ofitsiinyi visnyk Ukrainy, 7, art. 304. [in Ukrainian].

18. Buhera, S. I. (2007) Orhanizatsiino-pravovi pytannia rozvytku derzhavnoho rehuliuvannia v haluzi bdzhilnytstva Ukrainy. Candidate's thesis. Instytut derzhavy i prava im. V. M. Koretskoho. Kyiv. [in Ukrainian].

19. Ahrarne pravo Ukrainy (1996). V. Z. Yanchuk (Ed.). Kyiv: Yurinkom. [in Ukrainian].

20. Pytannia Ministerstva rozvytku ekonomiky, torhivli ta silskoho hospodarstva: Postanova Kabinetu Ministriv Ukrainy vid 11 veresnia 2019 r. 838. (2019) Ofitsiinyi visnyk Ukrainy, 74, art. 2588. [in Ukrainian].

21. Pro pravyla utrymannia bdzhil ta zainiattia bdzhilnytstvom. N. d. N. p. URL: http:// rada-bershad.gov.ua/novunu/pro-pravyla-utrymannya-bdzhil-ta-zaynyattya-bdzhilnyctvom. [in Ukrainian].

22. Reiestratsiia pasik. Sait holovnoho upravlinnia Derzhprodspozhyvsluzhby v Khersonskii oblasti. N. d. N. p.URL: https://dpss-ks.gov.ua/novini/reyestraciya-pasik [in Ukrainian].

23. Polozhennia pro departament tvarynnytstva Ministerstva ahrarnoi polityky ta prodovolstva Ukrainy. Nakaz Ministerstva ahrarnoi polityky ta prodovolstva Ukrainy vid 21 bereznia 2016, 96. (2016) N. p. URL: http:/ / minagro.gov.ua/uk/organic_ministry?nid=2995. [in Ukrainian].

24. Proekt Zakonu pro vnesennia zmin do deiakykh zakonodavchykh aktiv Ukrainy shchodo zakhystu bdzhilnytstva vid 14.02.2019. 10052. (2019) N. p. URL: http://w1.c1. rada.gov. ua/ pls/ zweb2/webproc4_1?pf3511=65508. [in Ukrainian]. 
Чвалюк А. Н., кандидат юридических наук, доцент кафедры специально-правовых дисциплин Донецкого государственного университета управления

(г. Мариуполь, Украина)

Чвалюк Н. В., соискатель степени высшего образования «бакалавр» Донецкого государственного университета управления

(г. Мариуполь, Украина)

\section{СОВРЕМЕННОЕ СОСТОЯНИЕ ПРАВОВОГО РЕГУЛИРОВАНИЯ ПЧЕЛОВОДСТВА В УКРАИНЕ}

Статья посвящена рассмотрению современного состояния правового регулирования пчеловодства. Анализ действующего законодательства, практики деятельности регуляторных органов и научных исследований показал отсутствие единой специализированной системы государственного управления в сфере пчеловодства и недостаточной эффективности государственного контроля. Осуществлена попытка привлечь внимание к следующему: отсутствию органов (должностных лищ) уполномоченных рассматривать дела об административных правонарушениях в сфере пчеловодства; неопределенности в подведомственности дел об административньх правонарушениях в сфере пчеловодства; отсутствию правовых норм определяющих лиц, которые имеют право составлять протоколы об административных правонарушениях в сфере пчеловодства. Предложено включить в положения Государственных строительных норм Украины следующее требование: «На участке пасеки ульи должны быть размещены: на расстоянии не менее 3 м от соседних садовых (дачных) участков летками, которые направлены от них; на расстоянии не менее 5 м от границы участка пасеки со стороны улицы».

Ключевые слова: пчеловодство, пасека, мед, управление, контроль, административная ответственность, Государственные строительные нормы Украины.

Chvaliuk A., Candidate of Law, Associate Professor of the Department of the Special Legal Disciplines Donetsk State University of Management (Mariupol, Ukraine)

Chvaliuk N.

Bachelor's Degree student of the Donetsk State University of Management (Mariupol, Ukraine)

\section{THE CURRENT STATE OF LEGAL REGULATION OF BEEKEEPING IN UKRAINE}

The article is devoted to the consideration of the current state of legal regulation of beekeeping. The analysis of the current legislation, the practice of regulatory bodies and scientific research has shown the lack of a single specialized system of public administration in the field of beekeeping and the lack of effectiveness of state control. It is determined that the system of specialized 
public administration bodies in the field of beekeeping has not been formed yet, which is confirmed by: the absence of specialized structural management elements at the level of the central executive body - the Ministry of Economy, Trade and Agriculture; lack of specialized structural elements at the local (regional and district) level; insufficient state control over compliance with legislation in the field of beekeeping; lack of legal norms governing the most significant issues of administrative liability for violations of legislation in the field of beekeeping; lack of apiary register. This lack of a specialized management system negatively affects the development of the industry and leads to mass violations of the rights of beekeepers.

It is concluded that modern social and environmental requirements, as well as European integration aspirations require to move away from traditional beekeeping practices and start applying new approaches to production, management and control and accordingly develop and adopt new legislation.

In order to eliminate conflicts between citizens engaged in beekeeping in their own backyard and their neighbours, it is proposed to include in the provisions of the State Building Regulations of Ukraine the following requirement: «Areas of flights that are directed from them; at a distance of not less than 5 meters from the boundary of the apiary on the street side».

Keywords: beekeeping, apiary, honey, management, control, administrative responsibility, State building norms of Ukraine. 